\title{
Sensitivity of Saccharomyces cerevisiae defective in TOR signaling pathway to carbonyl/oxidative stress
}

\author{
B. V. Valishkevych \\ Vassyl Stefanyk Precarpathian National University \\ 57, Shevchenko Str., Ivano-Frankivsk, Ukraine, 76018 \\ b.homza@ukr.net
}

\begin{abstract}
Aim. To investigate the influence of carbonyl/oxidative stress induced by glyoxal, methylglyoxal and hydrogen peroxide on the survival of Saccharomyces cerevisiae, defective for different parts of TOR-signaling pathway, grown on glucose or fructose. Methods. The assessment of number of colony-forming units to determine the yeast reproductive ability. Results. It was shown that at certain concentrations the mentioned above toxicants caused an increase in yeast survival, indicating the hormetic effect. Conclusions. The TOR signaling pathway is involved in the hormetic effect, but it is specific for each strain and depends on the type of carbohydrate in the incubation medium.
\end{abstract}

Keywords: Saccharomyces cerevisiae, glucose, fructose, TOR-signaling pathway, carbonyl/oxidative stress.

Introduction. The lack of nutrients and/or energy in the cell alternating with periods of their sufficient amount makes the cell to switch the stages of anabolism and catabolism [1]. TOR-pathway (target of rapamycin) is an important mechanism to respond to these needs. For the first time, this pathway has been described as a target of rapamycin, which is produced by bacteria Streptomyces hygroscopicus. Investigation of the $S$. cerevisae rapamycine-resistant mutants has clarified the mechanism of the antibiotic effects 2 . It should be noted that the baker's yeast $S$. cerevisae is an effective model system to study a variety of molecular mechanisms, because many of them are similar to those in higher eukaryotes [3-6].

In the early 1990s, using genetic screening the TOR 1 and TOR2 proteins in baker's yeast were identified as the mediators of the rapamycin toxic effects in the yeast $[7,8]$. TOR is a conservative atypical serine/threonine kinase that «senses» different internal and external signals regulating cell growth, protein biosynthesis and metabolism. TOR kinase can exist as two complexes: the rapamycin-sensitive TORC1 and rapamycin-resistant TORC2 $[9,10]$. Furthermore, the complexes are

(C) Institute of Molecular Biology and Genetics, NAS of Ukraine, 2014 controlled by different regulatory molecules and affect the variety of anabolic and catabolic processes [11]. The identification of TOR as an integral component of the signaling pathway PI3/AKT, suppressed at carcinogenesis, and cross-action between the tumor-suppressor p53-cascade and TOR, suggest a unique role of the TOR complex in processes of cell growth. In fact, there are various aspects of regulation of TOR kinase. One of them may be interaction between the kinase and the major signaling cascades of a cell, that allows its use as a target in treatments of cancer, diabetes, and obesity [12-14]. Although the TOR function is not well understood, it is known that it is a central component of the complex signaling system which regulates the size of cell, its proliferation and the size of a whole organism [14]. The connection between TOR-pathway and metabolism of some proteins and other biomolecules has been well studied $[15,16]$, whereas the interplay between TOR signaling cascade and carbohydrate metabolism is not clarified.

The inhibition or deletion of TOR signaling pathway extends chronological and replicative lifespan of yeast [17-19]. It is shown that the influence of TOR on yeast lifespan is intracellular: blocking TOR1 leads to 
the increased mitochondrial respiration during the logarithmic growth phase and simultaneously increases the generation of reactive oxygen species. It is also known that TOR takes part in the growth of yeast cells under stress conditions, since it regulates the transcriptional factor MSN2/4 [20, 21] which controls the gene expression in response to the environmental challenges, including heat shock and hydrogen peroxide exposure [22]. The cells lacking TOR1 are sensitive to osmotic stress, oxidative stress, high external $\mathrm{pH}$, and high or low temperature [20].

There are several lines of evidence indicating that genetic interference with TORC1 or its translation extends life span. TORC1 inhibits the SKN-1 and DAF-16 expression and activity, at least partially by increasing mRNA translation. TORC2 regulates the $\mathrm{SKN}-1$ nuclear occupancy in a nutrient-dependent manner. DAF-16 is required for longevity that derives from inhibition of TORC1, but not TORC2. SKN-1 is essential for the TORC1 or TORC 2 inhibition to extend life span. When TORC1 is inhibited, SKN-1 increases transcription of the TORC1 pathway genes in a feedback loop [23].

Why does TOR respond to the environmental stress? One explanation is that TOR as a central controller of cell growth may respond to several different types of stress to ensure that growth occurs only when overall conditions are favorable [20].

The phenomenon of hormesis as biphasic adaptive response to low doses of stressors, including reactive oxygen species, is widely known [24-26]. Hormesis takes part in the induction of cellular protection, and recent studies suggest that these protective effects are capable of slow aging in model organisms [27]. Other possible way to increase lifespan of organisms is calorie restriction, particularly restriction of carbohydrates, which is considered to be the most replicable strategy in the physiological aging slowdown and delay of the age-related pathological changes [28].

Recently, it has been shown that the rate of aging and reproductive ability of yeast $[29,30]$, as well as its resistance to stress depend on the concentration and type of monosaccharide in the cultivation medium [31]. Since the relationships between TOR-pathway and carbohydrates are not completely understood, the aim of this work is to investigate the effect of carbonyl/oxidative stress induced by glyoxal, methylglyoxal and hydrogen peroxide on the survival of yeast, defective in different parts of TOR-signaling pathway and grown on glucose or fructose.

Materials and methods. S. cerevisiae strains used in the study were: wild type JK9-3da with the following genotype MATa leu2-3,112 ura3-52 rmel trp1 his4 GAL + SH121 (JK9-3da, tor2::ADE2-3/YCplac111: :tor2-21ts) and SH221 (JK9-3da, tor1::HIS3-3 tor2: :ADE2-3/YCplac111::tor2-21ts) kindly provided by Professor Michael Hall (University of Basel, Switzerland). The strains are marked as follows: wt, $\Delta$ tor $1, \Delta$ tor 2 and $\Delta t \Delta$ or $1 \Delta t o r 2$. The JK9-3da were kept on YPD (yeast, pepton, dextrose) rich cultivation medium, the other three strains were kept on SD-Leu (synthetic dextrose medium without leucine) to prevent loss of the plasmid (YCplac111) [32].

Chemicals used: yeast extract, peptone («Fluka», Germany); glucose, fructose, glyoxal, methylglyoxal («Sigma», USA). All other reagents were from local suppliers (Ukraine) and were of analytical grade.

Yeast cells were grown at $28^{\circ} \mathrm{C}$ with shaking at 175 rpm in a liquid medium YPD containing $1 \%$ yeast extract, $2 \%$ peptone, and $2 \%$ glucose or fructose. Aliquots of experimental cultures were resuspended in the medium with glyoxal, methylglyoxal or hydrogen peroxide at appropriate concentrations and incubated for $1 \mathrm{~h}$ at $28{ }^{\circ} \mathrm{C}$. Control cells were incubated in the same way but without addition of toxicants. Reproductive ability was analyzed after yeast treatment with the respective reagent by plating in triplicate on YPD agar after proper dilution.

The plates were incubated at $28^{\circ} \mathrm{C}$ for one day and the colony forming units (CFU) counted [33]. Reproductive ability was expressed as percentage of total amount of cells plating on YPD agar.

Results and discussion. The carbonyl/oxidative stress is considered as a state resulting from the increasing concentrations of reactive carbonyl compounds and reactive oxygen species. They are harmful because of their ability to participate in nonenzymatic processes that are poorly controlled by cells. Such processes include, first of all, free radical oxidation and nonenzymatic glycation. The compounds like glyoxal, methylglyoxal, and hydrogen peroxide cause carbonyl and oxidative stress on the one hand, and on the other, they are the consequence of the mentioned above stresses [34-37]. The 
activity of antioxidant enzymes increased in response to the stressor effects. It is known that the TOR signaling pathway may regulate stress resistance in yeast [38].

Fig. 1, $A$, shows the survival of parental strain cells $(w t)$, incubated in a medium with glucose (left) or fructose (right) for $1 \mathrm{~h}$ under stress conditions. As can be seen, the survival of yeast in most cases decreased as compared to the control after cell incubation with all toxicants used in this study. It should be mentioned that the type of carbohydrate in the incubation medium also affects the survival of yeast cells, since after the treatment with glyoxal, methylglyoxal and hydrogen peroxide the cells grown on fructose showed higher viability than the glucose-grown cells. A similar effect was also observed in the $\Delta$ tor 1 strain (Fig. $1, B$ ) - under the stress conditions the fructose-grown cells (Fig. 1, $B$, right) survived better than yeast grown on glucose (Fig. 1, $B$, left). In the case of the $\Delta$ tor 2 mutant (Fig. $1, C$ ), no significant differences between yeast incubated with glucose and fructose were observed. However, the survival of yeast reduced after the incubation with glyoxal and methylglyoxal as compared to the control, whereas the incubation with hydrogen peroxide led to the opposite effect. This can be explained by the fact that hydrogen peroxide is less harmful than glyoxal or methylglyoxal at the concentrations used. In the case of the $\Delta$ tor $1 \Delta$ tor 2 double mutant (Fig. 1, D), we observed completely contrary situation: the cells grown on glucose (left) survived better than those grown on fructose (right). We suppose that this peculiarity can be explained by some compensatory mechanism in the $\Delta$ tor $1 \Delta$ tor 2 strain. For example, it is known that proteinkinases Snflp/AMP, Sch9, PKA, MAP similarly to the TOR are nutrient sensors, and perhaps they promote better survival of cells grown in a medium with glucose [39].

Thus, the parental strain demonstrated the highest sensitivity to glyoxal, methylglyoxal and hydrogen peroxide as compared with its derivatives. This is in accordance with the previous data showing that the inhibition of TOR genes promotes better survival due to compensatory mechanisms [39].

The determination of the number of colony-forming unit is a widely used test for the reproductive ability in yeast [33]. Therefore, next we compared the survival of yeast strains defective in different parts of TORsignaling pathway under carbonyl/oxidative stress indu- ced by different concentrations of hydrogen peroxide, glyoxal and methylglyoxal.

$\mathrm{H}_{2} \mathrm{O}_{2}$ is a small, uncharged molecule, therefore it can easily penetrate through the cell membrane and react with the cellular components, far away from the place of its synthesis. Hydrogen peroxide is a rather stable compound with not very high reactivity. However, an increase in the $\mathrm{H}_{2} \mathrm{O}_{2}$ intracellular concentration can be dangerous for the cell due to the production of highly reactive hydroxyl radical $\mathrm{OH}$ in the presence of transition metal ions [40].

Fig. 2 demonstrates that low concentration of hydrogen peroxide has hormetic effect. The parental strain $(w t)$ incubated with $25 \mathrm{mM}$ hydrogen peroxide in glu- cose had the highest colony-forming ability (CFU), whereas the wt cells grown in medium with fructose demonstrated this phenomenon at $50 \mathrm{mM}$ hydrogen peroxide. It is in accordance with the recent data, which showed that fructose defends the yeast against $\mathrm{H}_{2} \mathrm{O}_{2}$-induced stress better than glucose [31]. It also worth mentioning that $S$. cerevisiae JK9-3 da ( $w t)$ is found to be more resistant to hydrogen peroxide than $S$. cerevisiae YPH250. For example, the $S$. cerevisiae YPH250 ability to form colonies increased by $30 \%$ after yeast treatment with $2.5 \mathrm{mM} \mathrm{H}_{2} \mathrm{O}_{2}$ comparing to untreated control cells [24].

In the case of $\Delta$ tor $1 \Delta$ tor 2 , the highest $C F U$ was found at $5 \mathrm{mM}$ hydrogen peroxide regardless of the type of carbohydrate in the medium. Simultaneously, there was no clear hormetic effect in the single mutant strains $\Delta$ tor 1 and $\Delta$ tor 2 exposed to the same conditions. However, in the presence of glucose CFU gradually increased with increasing hydrogen peroxide concentration up to $2.5 \mathrm{mM}$, after which the CFU number decreased. The single mutants grown in the presence of fructose showed a decrease in the CFU number with increasing concentrations of hydrogen peroxide, and the hormetic effect was not found. It should also be noted that the survival of yeast incubated in fructose was significantly higher in parental strain $(w t)$ and single mutants ( $\Delta$ tor 1 and $\Delta$ tor 2 ) under the mentioned above conditions. Perhaps such yeast resistance to the stressors can be related to a higher intensity of oxidative processes in the presence of fructose, which stimulates the defensive mechanisms against stress [31, 34-35]. There were no significant differences for the $\Delta$ tor $1 \Delta$ tor 2 cells incubated with different carbohydrates. 

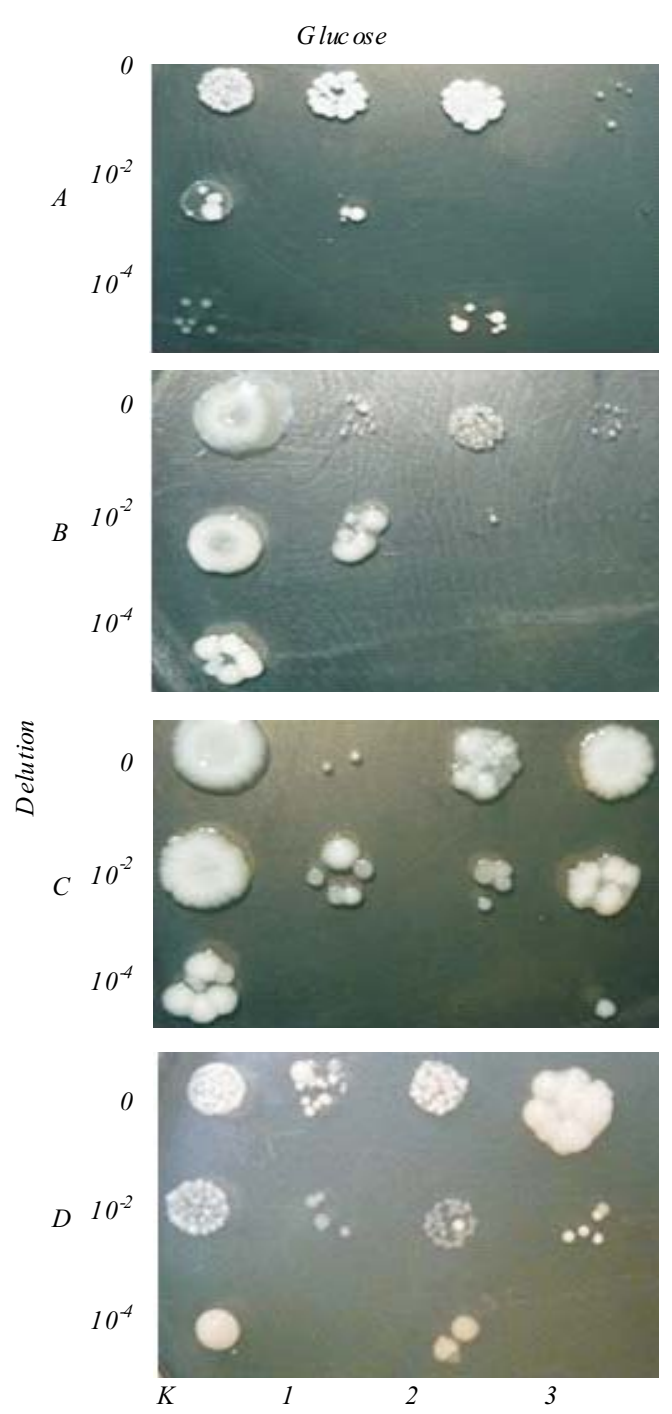

Glyoxal is highly reactive dialdehyde, which is mainly formed in the cell as an intermediate of glycation $[34,41]$. Its formation is also associated with the glyoxylate metabolism [37, 42].

Now let us consider the survival of yeast $S$. cerevisi$a e$, defective in different parts of TOR-signaling pathway, under conditions of the carbonyl/oxidative stress induced by glyoxal (Fig. 3). A significant increase in survival was observed for the strains $w t$ and $\Delta t o r 2$ exposed to glyoxal at concentration of $5 \mathrm{mM}$ in the presence of glucose. At the same time, there were no hormetic effects in the yeast cells incubated in the presence of fructose, as well as in $\Delta$ tor 1 and $\Delta$ tor $1 \Delta$ tor 2 incubated with any carbohydrate used. Additionally, CFU for $w t$ and $\Delta t o r 2$ strains was higher in the presence of fructose than of glucose. There was opposite situation un-
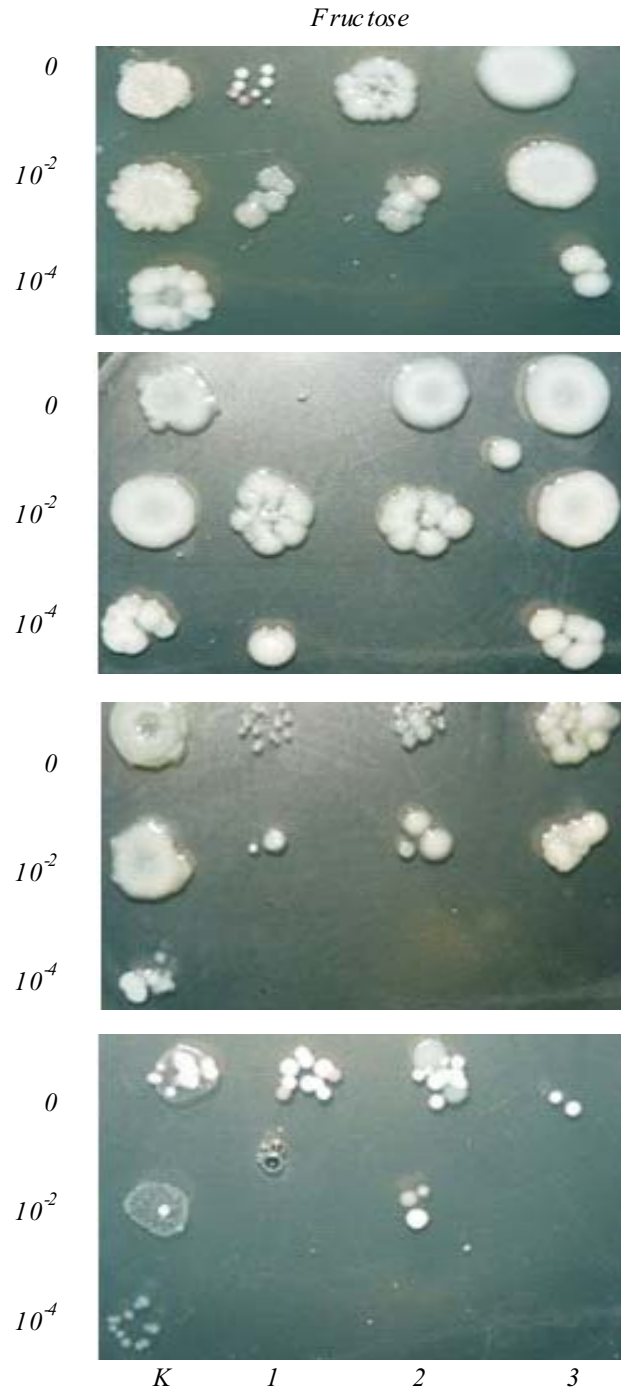

Fig. 1. The effect of glyoxal, methylglyoxal and hydrogen peroxide ( $1 \mathrm{~h}$ stress) on the survival of $S$. cerevisiae parental strain $(w t)(A)$, $\Delta$ torl $(B), \Delta$ tor $2(C)$ and $\Delta$ tor $1 \Delta$ tor $2(D)$ grown in medium with glucose (left) or fructose (right): $K-$ Control; 1 - $800 \mathrm{mM}$ glyoxal; 2 $20 \mathrm{mM}$ methylglyoxal; 3 $50 \mathrm{mM} \mathrm{H}_{2} \mathrm{O}_{2}$. Cells dilutions in yeast suspension are indicated on the vertical

der conditions with $5 \mathrm{mM}$ glyoxal: the survival in the presence of glucose was significantly higher compared to fructose-grown cells. This trend continued at most concentrations of glyoxal used in wild strain and single mutants. We did not find any similar trend in the double mutant strain.

Methylglyoxal is a by-product of glycation, metabolism of carbohydrates, ketone bodies, threonine catabolism, etc. [37, 42, 43]. It is also known that methylglyoxal is formed as a result of nonenzymatic degradation of phosphotriose - intermediates of glycolysis [36, 42, 43]. Formation of methylglyoxal in this case is due to the elimination of phosphate with glyceraldehyde-3phosphate and dihydroxyacetone phosphate [37, 44].

Fig. 4 demonstrates the survival of $S$. cerevisiae cells, defective in different parts of TOR-signaling path- 


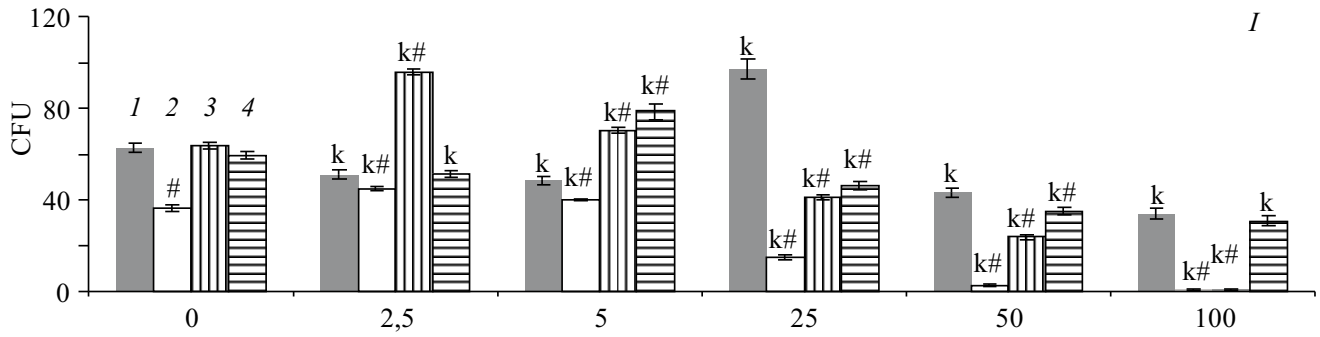

Fig. 2. The effects of various concentrations of hydrogen peroxide on the reproductive ability of

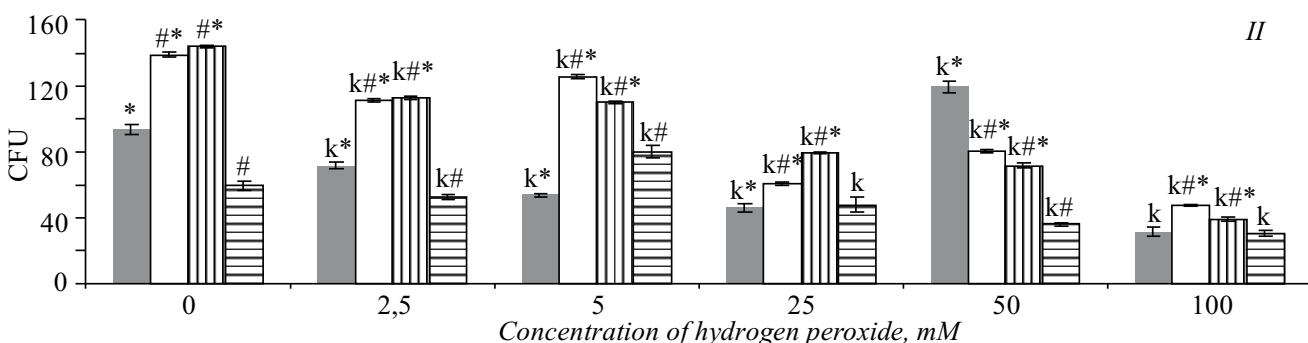

cerevisiae parental strain $(w t)$ and its derivatives $(\Delta \operatorname{tor} 1, \Delta$ tor 2 , and $\Delta$ tor $1 \Delta$ tor 2$)$ grown on glucose $(I)$ or fructose $(I I)(M \pm m, n=$ $=4-8)$. Significantly different from the $(*)$ respective glucosegrown strain, (k) control (without hydrogen peroxide), (\#) parental strain with $\mathrm{P}<0.05$

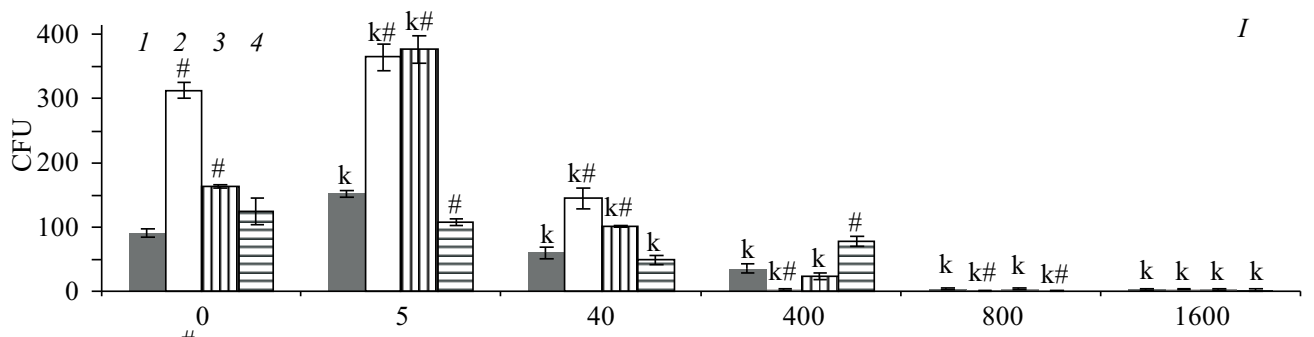

Fig. 3. The effects of various concentrations of glyoxal on the reproductive ability of $S$. cerevisiae parental strain $(w t)$ and its derivatives ( $\Delta$ tor $1, \Delta t o r 2$, and $\Delta$ tor $1 \Delta$ tor 2$)$ grown on glucose (I) or fructose (II) $(M \pm m, n=$ = 3-6). Significantly different from the $(*)$ respective glucosegrown strain, $(k)$ control (without glyoxal), (\#) parental strain with $\mathrm{P}<0.05$

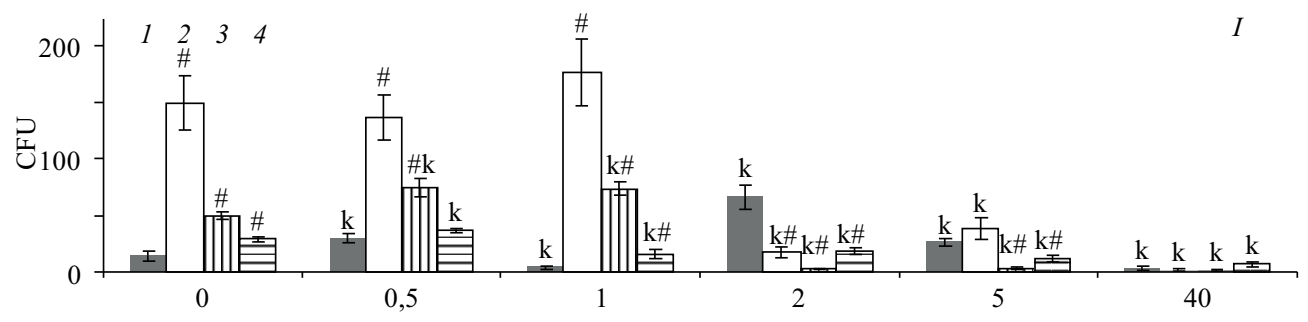

Fig. 4. The effects of various concentrations of methylglyoxal on

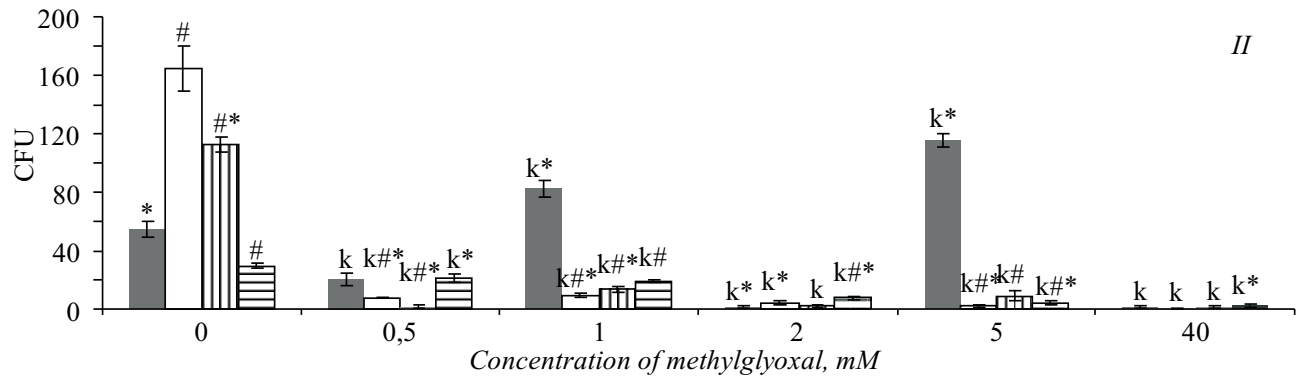
the reproductive ability of $S$. cerevisiae parental strain $(w t)$ and its derivatives $(\Delta t o r 1, \Delta t o r 2$, and $\Delta$ tor $\Delta$ tor 2$)$ grown on glucose $(I)$ or fructose (II) $(M \pm m, n=3-7)$. Significantly different from the $(*)$ respective glucose-grown strain, (k) control (without methylglyoxal), (\#) parental strain with $\mathrm{P}<0.05$ 
way, under methylglyoxal exposure. In the parental strain (wt) the highest CFU was observed in the presence of glucose and $0.5,2$, and $5 \mathrm{mM}$ methylglyoxal, whereas in the cells, grown on fructose, this phenomenon occurred at 1 and $5 \mathrm{mM}$ methylglyoxal. In the $\Delta$ tor $1 \Delta$ tor 2 , hormetic effect occurred at $0.5 \mathrm{mM}$ methylglyoxal in the cells incubated with glucose, and in the $\Delta$ tor 2 it took place after incubation with $1 \mathrm{mM}$ methylglyoxal on the same carbohydrate. There was no hormetic effect in another single mutant $\Delta$ tor 1 with any of the studied carbohydrates. Also, we found higher survival of mutant cells grown in the presence of glucose than of those grown with fructose in most cases.

Thus, comparing the influence of hydrogen peroxide and glycation agents (glyoxal and methylglyoxal) on the yeast grown on glucose or fructose one may suggest that the toxicants demonstrate hormetic effects.

Moreover, the effect is specific for the strains and depends on the type of carbohydrate in the incubation medium. Hormetic effect was found in parental strain $(w t)$ at concentrations: $25 \mathrm{mM}$ hydrogen peroxide (increased by $55 \%$ comparing to the control), $5 \mathrm{mM}$ glyoxal (increased by $68 \%$ comparing to the control) and $2 \mathrm{mM}$ methylglyoxal (4.6-fold higher comparing to the control) in glucose, whereas in the presence of fructose the largest number of colonies was detected at $50 \mathrm{mM}$ hydrogen peroxide (increased by $28 \%$ comparing to the control) and $5 \mathrm{mM}$ methylglyoxal (2.1-fold higher comparing to the control). In the case of $\Delta$ torl, the highest CFU was found at $2.5 \mathrm{mM}$ of hydrogen peroxide (increased by $22 \%$ to the control) and $5 \mathrm{mM}$ of glyoxal (increased by $17 \%$ comparing to the control) in the glucose containing medium. In the $\Delta$ tor 2 strain, hormetic effects were revealed at $2.5 \mathrm{mM}$ hydrogen peroxide (increased by $50 \%$ comparing to the control), $5 \mathrm{mM}$ glyoxal (2.3-fold higher comparing to the control) and 1 $\mathrm{mM}$ methylglyoxal (increased by $48 \%$ comparing to the control) with glucose. The strain $\Delta$ tor $1 \Delta$ tor 2 incubated with $5 \mathrm{mM}$ hydrogen peroxide (increased by $32 \%$ comparing to the control) and $0.5 \mathrm{mM}$ methylglyoxal (increased by $25 \%$ comparing to the control) in glucose had the highest CFU, whereas the cells, grown in medium with fructose, demonstrated this phenomenon only at $5 \mathrm{mM}$ hydrogen peroxide (increased by $34 \%$ comparing to the control). The mutant strains are characterized by a higher proliferative activity, which may be explained by the involvement of important compensatory mechanisms, in particular, the kinases Snflp/ AMP, Sch9, PKA, MAP.

Acknowledgements. The author is grateful to her supervisor Dr. Halyna Semchyshyn, and to Prof. Michael Hall for providing the strains of $S$. cerevisiae.

Чутливість дріжджів Saccharomyces cerevisiae, дефектних за різними ділянками сигнального шляху TOR, до карбонільного/оксидативного стресу

\section{Б. В. Валішкевич}

Резюме

Мета. Дослідити вплив карбонільного/оксидативного стресу, індукованого гліоксалем, метилгліоксалем та пероксидом водню, на виживання штамів $S$. сегеvisiae, дефектних за різними ділянками TOR-сигнального иляху, за умов їхнього росту у середовищі із глюкозою чи фруктозою. Методи. Оцінка репродуктивної здатності методом визначення кількості колонієутворювальних одиниць. Результати. Показано, щзо у певних концентраціях дія вищезазначених агентів викликає підвищення рівня виживання. Це свідчить про наявність горметичного ефекту. Висновки. Шлях TOR залучений до горметичного ефекту всіх використаних токсикантів, проте наявність даного ефекту є специфічною для кожного итаму та залежить від типу вуглеводу у середовищі інкубаиії.

Ключові слова: Saccharomyces cerevisiae, глюкоза, фруктоза, сигнальний шлях TOR, карбонільний/оксидативний стрес.

Чувствительность дрожжей Saccharomyces cerevisiae, дефектных по различным участкам сигнального пути TOR, к карбонильному/окислительному стрессу

\section{Б. В. Валишкевич}

Резюме

Цель. Исследовать влияние карбонильного/окислительного стресса, индуцированного глиоксалем, метилглиоксалем и пероксидом водорода, на выживание штаммов Saccharomyces cerevisiae, дефектных по разным участками TOR-сигнального пути, в условиях их роста в среде с глюкозой или фруктозой. Методы. Оиенка репродуктивной способности в результате определения количества колоний-образуюших единиц. Результаты. Показано, что в определенных концентрациях действие вымеупомянутых агентов вызывает повышение уровня выживания, что свидетельствует о наличии горметического эффекта. Выводы. Путь TOR вовлечен в горметический эффект всех использованных токсикантов, однако наличие данного эффекта является специфическим для каждого итамма и зависит от типа углевода в среде инкубаичии.

Ключевые слова: Saccharomyces cerevisiae, глюкоза, фруктоза, TOR-сигнальный путь, карбонильный/окислительный cmpecc.

\section{REFERENCES}

1. Laplante $M$, Sabatini DM. mTOR signaling in growth control and disease. Cell. 2012;149(2):274-93. 
2. Heitman J, Movva NR, Hall MN. Targets for cell cycle arrest by the immunosuppressant rapamycin in yeast. Science. 1991;253 (5022):905-9.

3. Lushchak VI. Budding yeast Saccharomyces cerevisiae as a model to study oxidative modification of proteins in eukaryotes. $A c-$ ta Biochim Pol. 2006;53(4):679-84.

4. Fontana L, Partridge L, Longo VD. Extending healthy life spanfrom yeast to humans. Science. 2010;328(5976):321-6.

5. Rockenfeller P, Madeo F. Ageing and eating. Biochim Biophys Acta. 2010;1803(4):499-506.

6. Summers $D W, C y r D M$. Use of yeast as a system to study amyloid toxicity. Methods. 2011;53(3):226-31.

7. Kunz J, Henriquez R, Schneider U, Deuter-Reinhard M, Movva $N R$, Hall MN. Target of rapamycin in yeast, TOR2, is an essential phosphatidylinositol kinase homolog required for G1 progression. Cell. 1993;73(3):585-96.

8. Cafferkey R, Young PR, McLaughlin MM, et al. Dominant missense mutations in a novel yeast protein related to mammalian phosphatidylinositol 3-kinase and VPS34 abrogate rapamycin cytotoxicity. Mol Cell Biol. 1993;13(10):6012-23.

9. Warburg $O$, Posener K, Negelein E. Uber den stoffwechsel der carcinomzelle. Die Naturheilkunde. 1924;152:309-44.

10. Weinberg RA. The molecular basis of oncogenes and tumor suppressor genes. Ann N Y Acad Sci. 1995;758:331-8.

11. Laplante M, Sabatini DM. mTOR signaling at a glance. $J$ Cell Sci. 2009;122(Pt 20):3589-94.

12. Bierer BE, Jin YJ, Fruman DA, Calvo V, Burakoff SJ. FK 506 and rapamycin: molecular probes of T-lymphocyte activation. Transplant Proc. 1991;23(6):2850-5.

13. Sarbassov DD, Ali SM, Sabatini DM. Growing roles for the mTOR pathway. Curr Opin Cell Biol. 2005;17(6):596-603.

14. Vezina C, Kudelski A, Sehgal SN. Rapamycin (AY-22,989), a new antifungal antibiotic. I. Taxonomy of the producing streptomycete and isolation of the active principle. J Antibiot (Tokyo). 1975;28(10):721-6.

15. Efeyan A, Zoncu R, Sabatini DM. Amino acids and mTORC1: from lysosomes to disease. Trends Mol Med. 2012;18(9):524-33.

16. Appenzeller-Herzog C, Hall MN. Bidirectional crosstalk between endoplasmic reticulum stress and mTOR signaling. Trends Cell Biol. 2012;22(5):274-82.

17. $H a C W, H u h W$. Rapamycin increases rDN stability by enhancing association of Sir2 with rDNA in Saccharomyces cerevisiae. Nucleic Acids Res. 2011;39(4):1336-50.

18. Medvedik O, Lamming DW, Kim KD, Sinclair DA. MSN2 and MSN4 link calorie restriction and TOR to sirtuin-mediated lifespan extension in Saccharomyces cerevisiae. PLoS Biol. 2007;5 (10): 261.

19. Brant JM, Beck S, Dudley WN, Cobb P, Pepper G, Miaskowski $C$. Symptom trajectories in posttreatment cancer survivors. Cancer Nurs. 2011;34(1):67-77.

20. Crespo JL, Hall MN. Elucidating TOR signaling and rapamycin action: lessons from Saccharomyces cerevisiae. Microbiol Mol Biol Rev. 2002;66(4):579-91.

21. Beck T, Hall MN. The TOR signalling pathway controls nuclear localization of nutrient-regulated transcription factors. Nature. 1999;402(6762):689-92.

22. Semchyshyn $H$. Hydrogen peroxide-induced response in $E$. coli and S. cerevisiae: different stages of the flow of the genetic information. Cent Eur J Biol. 2009; 4(2):142-53.

23. Robida-Stubbs $S$, Glover-Cutter K, Lamming DW, et al. TOR signaling and rapamycin influence longevity by regulating SKN-1/ Nrf and DAF-16/FoxO. Cell Metab. 2012;15(5):713-24.
24. Semchyshyn HM. Hormetic concentrations of hydrogen peroxide but not ethanol induce cross-adaptation to different stresses in budding yeast. Int J Microbiol. 2014;2014:485792.

25. Lushchak VI. Dissection of the hormetic curve: analysis of components and mechanisms. Dose Response. 2014;12(3):466-79.

26. Bayliak MM, Burdyliuk NI, Izers'ka LI, Lushchak VI. Concentration-dependent effects of rhodiola rosea on long-term survival and stress resistance of yeast Saccharomyces cerevisiae: the involvement of YAP 1 and MSN2/4 regulatory proteins. Dose Response. 2013;12(1):93-109.

27. Mirisola $M G$, Longo $V D$. A radical signal activates the epigenetic regulation of longevity. Cell Metab. 2013;17(6):812-3.

28. Cornelius C, Perrotta R, Graziano A, Calabrese EJ, Calabrese V. Stress responses, vitagenes and hormesis as critical determinants in aging and longevity: Mitochondria as a «chi». Immun Ageing. 2013;10(1):15.

29. Ljungdahl PO, Daignan-Fornier B. Regulation of amino acid, nucleotide, and phosphate metabolism in Saccharomyces cerevisiae. Genetics. 2012;190(3):885-929.

30. Semchyshyn HM, Lozinska LM, Miedzobrodzki J, Lushchak VI. Fructose and glucose differentially affect aging and carbonyl/ oxidative stress parameters in Saccharomyces cerevisiae cells. Carbohydr Res. 2011;346(7):933-8.

31. Semchyshyn HM, Lozinska LM. Fructose protects baker's yeast against peroxide stress: potential role of catalase and superoxide dismutase. FEMS Yeast Res. 2012;12(7):761-73.

32. Helliwell SB, Howald I, Barbet N, Hall MN. TOR2 is part of two related signaling pathways coordinating cell growth in Saccharomyces cerevisiae. Genetics. 1998;148(1):99-112.

33. Meynel J. Meynell GG, Meynell E. Experimental microbiology (Theory and Practice). Moscow, Mir, 1967; 347 p.

34. Semchyshyn HM. Reactive carbonyl species in vivo: generation and dual biological effects. Scientific World Journal. 2014; 2014:417842.

35. Semchyshyn HM. Fructation in vivo: detrimental and protective effects of fructose. Biomed Res Int. 2013;2013:343914.

36. Semchyshyn HM, Lushchak VI. Interplay between oxidative and carbonyl stresses: molecular mechanisms, biological effects and therapeutic strategies of protection. Oxidative Stress - Molecular mechanisms and biological effects. InTech. 2012; 15-46.

37. Lozins'ka LM, Semchyshyn HM. Biological aspects of non-enzymatic glycosylation. Ukr Biokhim Zh. 2012;84(5):16-37.

38. Semchyshyn HM, Bayliak MM, Lushchak VI. Starvation in yeasts: biochemical aspects. Biology of starvation in humans and other organisms. Ed. TC. Merkin. New York, Nova Science, 2011;103-50.

39. Homza BV, Vasyl'kovs'ka RA, Semchyshyn HM. Defects in TOR regulatory complexes retard aging and carbonyl/oxidative stress development in yeast Saccharomyces cerevisiae. Ukr Biokhim Zh. 2014;86(1):85-92.

40. Lushchak VI. Oxidative stress and mechanisms of protection against it in bacteria. Biochemistry (Mosc). 2001;66(5):476-89.

41. Semchyshyn HM. Defects in antioxidant defence enhance glyoxal toxicity in the yeast Saccharomyces cerevisiae. Ukr Biokhim Zh. 2013;85(5):50-60.

42. Turk Z. Glycotoxines, carbonyl stress and relevance to diabetes and its complications. Physiol Res. 2010;59(2):147-56.

43. Kalapos MP. Methylglyoxal in living organisms: chemistry, biochemistry, toxicology and biological implications. Toxicol Lett. 1999;110(3):145-75.

44. Richard JP. Mechanism for the formation of methylglyoxal from triosephosphates. Biochem Soc Trans. 1993;21(2):549-53.

Received 02.04.14 